\title{
International Law of State Responsibility and covid-19: An Ideology Critique
}

\author{
Robert Knox* and Ntina Tzouvala**
}

In its initial stages, international legal discourse around covid-19 focused heavily on two narrow questions: first, the international legality of lockdowns, and secondly whether China could be held legally responsible for the pandemic. In September 202O, Donald Trump called upon the United Nations ('UN') to find China responsible for Covid-19. Similarly, Australia called for a fact finding mission over the question of China's state responsibility. ${ }^{1}$ For its part, China has rebuffed such claims, at one point seeming to place responsibility for the pandemic with the World Health Organization ('WHO') or, more recently, with imported frozen food that allegedly triggered a super-spreader event at the Wuhan food market. ${ }^{2}$ These accusations are not simply of concern to a small number of government-employed international lawyers, who might be called upon to put them in motion. The popular international law blog EJIL: Talk! announced in late 2020 that its most read post for the year was a piece by Peter Tzeng on the possibility of holding China internationally responsible for the pandemic. ${ }^{3}$ Tzeng's piece was part of — and itself generated - a flurry of academic commentary on China's potential legal responsibility. ${ }^{4}$

* Robert Knox is a Senior Lecturer at Liverpool Law School.

** Ntina Tzouvala is a Senior Lecturer, at the ANU College of Law.

1 Daniel Hurst, 'Australia Insists WHO Inquiry into Covid Origin Must Be Robust, despite China Tensions', The Guardian (online, 28 December 2020) < https://www.theguardian.com/ world $/ 2020 / \mathrm{dec} / 29 /$ australia-insists-who-inquiry-into-covid-origin-must-be-robust-despite -china-tensions $>$.

2 Bang Xiao, 'China's Large-Scale Coronavirus Tests on Imported Frozen Foods May Put More Australian Exports on Hold', ABC News (online, 21 November 2020) <https://www.abc.net .au/news/2020-11-21/china-tests-imported-frozen-food-for-coronavirus/12895284>.

3 Dapo Akande, 'Happy New Year and Our Most Read Posts of 2020', EJIL: Talk! (Blog Post, 2January 2021)<https://www.ejiltalk.org/our-most-read-posts-of-202o/>; PeterTzeng, 'Taking China to the International Court of Justice Over COVID-19', EJIL:Talk! (Blog Post, 2 April 2020) $<$ https://www.ejiltalk.org/taking-china-to-the-international-court-of-justice-over-covid-19>.

4 Johanna Aleria Lorenzo, 'To Sue or Not To Sue: Enforcing the Obligation To Notify under the International Health Regulations', Völkerrechtsblog (Blog Post, 4 June 2020) <https:// voelkerrechtsblog.org/to-sue-or-not-to-sue>; 'Episode 2: WHO let the bats out?' EJIL: The Podcast! (European Journal of International Law, 5 May 2020) <https://player.capti vate.fm/episode/a125dc3e-6feo-4fgc-9a2b-a89oa5bd7679>; David Fidler, 'COVID-19 and

(C) ROBERT KNOX AND NTINA TZOUVALA, 2022 | DOI:10.1163/26660229-03901009

This is an open access article distributed under the terms of the CGC BY 4tolicense. Brill. com04/26/2023 03:25:30AM 
Of course, one could retort here that the combination of veto rights at the UN Security Council, the absence of obvious grounds for the International Court of Justice's ('ICJ') jurisdiction and the operation of sovereign immunity make the possibility of China (or any other state for that matter) facing proceedings over COVID-19 wildly implausible. Questions of proof-both in the light of non-cooperation but also sheer factual and scientific uncertaintyand causation make the suggestion that anyone will be held internationally responsible sound like a cruel joke. One would be tempted to dismiss, then, these discussions as being irrelevant, as the expressions of an out-of-touch profession on the part of lawyers and simple rhetoric on the part of states.

However, it is important to resist this realist impulse. It cannot explain why these 'impossible' accusations have recurred with such frequency in the discourse around the pandemic. Indeed, from this perspective it is the sheer implausibility of these legal schemes that makes their popularity worth interrogating. Why, in such a practice-orientated field as law, does such a seemingly impractical set of accusations recur? We posit that law, including international law, has many functions: it represses, it distributes resources, opportunities and violence, and it produces representations of our relationship with the world, or, in other words, it operates as an ideology. Our intervention is concerned with this latter ideological function of law. In particular, we seek to detect and critique the specific representations about the relationship between states, capital, and global disaster that are implicitly articulated through discussions of state responsibility for the pandemic.

Before we do this, it is important to clarify two things about our understanding of 'ideology'. References to ideology in legal writings are generally directed against one's opponents alleging that said opponents have made a mistake in applying/deciding the law, often in bad faith, because of their ideology. ${ }^{5}$ More

International Law: Must China Compensate Countries for the Damage?', Just Security (Web Page, 27 March 2020) <https://www.justsecurity.org/69394/covid-19-and-international-law -must-china-compensate-countries-for-the-damage-international-health-regulations/>; Hans Huremagić and Fritz Kainz, 'COVID-19, China and International Aviation Law: A Ticket to The Hague?', EJIL: Talk!, (Blog Post, 13 July 2020) <https://www.ejiltalk.org/covid-19-china -and-international-aviation-law-a-ticket-to-the-hague >; for a broader argument see Martins Paparinskis, 'The Once and Future Law of State Responsibility' (2020) 114(4) American Journal of International Law 618.

5 Duncan Kennedy, 'The Hermeneutic of Suspicion in Contemporary American Legal Thought' (2014) 25(2) Law and Critique 91. 
broadly, in legal and everyday parlance, ideology is equated to beliefs and ideas, namely intellectual constructions about the world that exist mainly in our (or our opponents') heads and can motivate action.

Our own understanding departs from these common-sense approaches to ideology. First, we locate the operation of ideology neither as epiphenomenal to law's 'true' meaning and function nor as a distortion that is introduced by bad-faith or careless actors, but rather as inherent to law's core concepts, doctrines and procedures. A typical example here would be the individual legal subject. Marxist, feminist, critical race and psychoanalytic approaches have all centered this individual legal subject and shown that far from being a natural, self-evident unit it rather represents the free and equal commodityowner essential for capitalist exchange, ${ }^{6}$ a metonym for masculinity ${ }^{7}$ or whiteness ${ }^{8}$ or a desperate effort to assume a unitary, rational self where there is none to be found. ${ }^{9}$ Along with these critical traditions, we locate ideology to the law's core rather than to mistakes or (moral) failures in the course of its application.

Secondly, ideology is not simply the ideas that individuals carry in their heads, but rather it has a material existence. ${ }^{10}$ Legal ideology is not reducible to explicit articulations of legal values. Instead, it emerges from the material practices of legal institutions, such as the police, administrative bodies, and courts. This material life of ideology is crucial. What separates our own belief in the existence of unicorns from the widespread belief in individuals being self-evident, rational, autonomous legal subjects is not that the latter idea is closer to reality than the former. Rather, the latter proposition is embedded in a dense web of social practices and institutions that put it into action on a

6 Evgeniǐ Bronislavovich Pashukanis, 'The General Theory of Law and Marxism', tr Peter B Maggs in, Pashukanis: Selected Writings on Marxism and Law, ed Piers Beirne and Robert Sharlet (Academic Press, 1980) 37. The most comprehensive treatment of ideology and international law from a Marxian perspective is Susan Marks, The Riddle of All Constitutions: International Law, Democracy, and the Critique of Ideology (Oxford University Press, 200o). For an overview of Marxist approaches see Robert Knox, 'Marxist Approaches to International Law' in Anne Orford, Florian Hoffmann and Martin Clark (eds), The Oxford Handbook of the Theory of International Law (Oxford University Press, 2016) 306 .

7 Hilary Charlesworth and Christine Chinkin, The Boundaries of International Law: A Feminist Analysis (Manchester University Press, 2000).

8 Brenna Bhandar, Colonial Lives of Property: Law, Land, and Racial Regimes of Ownership (Duke University Press, 2018).

9 Maria Aristodemou, 'Freedom in the Free World: the Extimate Becomes the Law' (2016) 48 International Journal of Law and Psychiatry 85.

10 See Louis Althusser, Lenin and Philosophy and Other Essays, tr Ben Brewster (Monthly Review Press, 2001) 127. 
daily basis. In this respect, the ideology of individualism that animates liberal legal systems is not simply a mirage. It has real effects in the world, while at the same time playing a crucial role in the mystification of social relations, which are now perceived as relations between individuals. ${ }^{11}$

In international law, of course, it is typically the state that is assumed to be the essential unit of analysis. In turn, this ideological position (re)creates the world in particular ways. Once an international lawyer accepts this proposition both domestic and international social, economic and political relations become either entirely invisible or at the very least analytically secondary to the primacy of a state that is both imagined and created through international law as unitary, and autonomous. Think of the structure of investor-state dispute settlement in international investment law. The form of the procedure assumes the state as a unitary will, imposing itself upon a private corporation. What is lost in this material articulation of international legal ideology is the relationship between local communities, the environment, Indigenous peoples, the foreign investor, the host state as well as the state of the shareholders, and international institutions that have been promoting foreign investment as the only path to development. ${ }^{12}$ By reducing these complex relationships into a binary opposition (investor $\mathrm{v}$ state) international law invisibilises both the constitutive role of imperialism in constantly creating and re-creating the state (especially in the Global South) ${ }^{13}$ and also relationships of class, gender or race on the national level.14

11 See Nicos Poulantzas, Political Power and Social Classes, tr Timothy O'Hagan (Verso Books, 1978) 128. For an account of how this operates in the context of human rights law see Robert Knox, 'A Marxist Approach to RMT v the United Kingdom' in Damian Gonzalez-Salzberg and Loveday Hodson (eds), Research Methods for International Human Rights Law: Beyond the Traditional Paradigm (Routledge, 2020) 13.

12 On the interplay between international investment law with environmental concerns and/or local communities see Kate Miles, The Origins of International Investment Law: Empire, Environment, and the Safeguarding of Capital (Cambridge University Press, 2013); Columbia Center on Sustainable Development, 'International Investment and the Rights of Indigenous Peoples' (Workshop Outcome Document, 16 November 2016) <http:// ccsi.columbia.edu/files/2016/11/Workshop-on-International-Investment-and-the-Rights -of-Indigenous-Peoples-Outcome-Document-November-2016.pdf ; Nicolás M Perrone, "The "Invisible" Local Communities: Foreign Investor Obligations, Inclusiveness, and the International Investment Regime' (2019) 113 American Journal of International Law Unbound 16.

13 On the state-making functions of international law see Ntina Tzouvala, 'Civilization' in Jean d'Aspremont and Sahib Singh (eds), Concepts for International Law: Contributions to Disciplinary Thought (Edward Elgar Publishing, 2019) 83; Rose Parfitt, The Process of International Legal Reproduction: Inequality, Historiography, Resistance (Cambridge University Press, 2019).

14 On the subjugation of women's interests by classical accounts of the right to selfdetermination see Karen Knop, Diversity and Self-Determination in International Law 
With this understanding of international legal ideology as foundational and material in mind, we proceed to discussions over CoviD-19 and international responsibility for the pandemic. We argue that these debates both hinge upon and mystify two core aspects of contemporary global capitalism: first, the intensification of inter-imperial rivalry between the United States ('US') and China; and secondly, the increased transnationalisation of production and its implication with the accelerating climate disaster of our times. In this context, state responsibility as a concrete legal form does two things. First, it reifies the state as the primary agent of 'the international' at the precise point when production is assuming fragmented, transnational characteristics. ${ }^{15}$ In the context of this fragmentation, state responsibility offers a legal way of laying the blame for a complex international phenomenon at the feet of one's geopolitical rivals. Secondly, state responsibility in this context enacts a particular theory of causation. Within the universe of state responsibility complex events can be traced with a certain degree of plausibility and in a linear way back to the acts and omissions of one or the other state. In the following sections, we will show that both these ideological propositions are particular representations of one's relationship with the world that seek to make obvious and to legitimise specific political choices in the international realm.

\section{$3 \quad$ State Responsibility in the Shadow of Imperial Rivalry}

Attempting to invoke the state responsibility of another state for a given state of affairs implicitly disavows one's own responsibility for that same state of affairs, especially in the light of intensifying geopolitical and economic competition between China and the US. In the context of COVID-19, therefore, such

(Cambridge University Press, 2002). On the absence of a non-moralistic understanding of exploitation from international law see Susan Marks, 'Exploitation as an International Legal Concept' in Susan Marks (ed), International Law on the Left: Re-examining Marxist Legacies (Cambridge University Press, 2008) 281.

15 In this respect, our intervention is in close conversation with the contribution of Quintana and Uriburu at the AJIL Agora on Covid-19: Francisco-José Quintana and Justina Uriburu, 'Modest International Law: COVID-19, International Legal Responses, and Depoliticization' (2020) 114(4) American Journal of International Law 687. Our main departure from Quintana's and Uriburu's approach is that we treat professional impulses as being reflective-in however a mediated way-of bigger transformations of global capitalism. For an earlier articulation of some of the arguments we are putting forward here, see Ntina Tzouvala, 'COVID-19 Symposium: The Combined and Uneven Geography of COVID-19, or on Law, Capitalism and Disease' Opinio Juris (Blog Post, 2 April 2020) $<$ http://opiniojuris.org/2020/o4/o2/covid-19-symposium-the-combined-and-uneven -geography-of-covid-19-or-on-law-capitalism-and-disease/>. 
invocations represent attempts by governments to deflect attention from their own responsibility for, and handling of, the coviD-19 pandemic. This deflection has been especially important in the context of the US and Europe, where states have been remarkably ineffective in tackling the crisis. The severity of these failures of governance has been heightened through comparisons with other governments encompassing the 'developed' world—like Australia and New Zealand — and, more embarrassingly, 'less-developed' states.

In this respect, invocations of state responsibility have had the effect of deflecting attention from remarkable governance failures and what Danchin et al have described as 'unequal burdens and the equality paradox', ${ }^{16}$ where far from 'bringing together' the 'international community' the virus has sharpened pre-existing inequalities in important ways. Commentators have flagged, for instance, a now infamous article and accompanying map published in early 2020 by Forbes. The piece claimed that the US, the United Kingdom ('UK') and the Netherlands were the three most prepared states for an epidemic, ${ }^{17}$ while East Asian states that have dealt with CoviD-19 relatively successfully, including Vietnam, Taiwan or Japan, were in the 'more prepared' category. Most African states were classified under the 'least prepared' category and shown in the colour red, which is generally associated with danger and imminent threat. ${ }^{18}$ In reality, African states have had a variety of responses to COVID-19 and some, including Lesotho, Senegal or Nigeria, took early and decisive measures. Upon reflection, this map appears more reflective of Western confidence and of a desire to understand and govern the world through indexes, rankings and maps that classify states in three categories than with reality.

This failure of (most) Western states to protect the lives and livelihoods of their citizens needs to be understood as part of the wider political-economic transformations that have characterised the world since the early 2ooos. This period has been one of relative hegemonic decline in which the US and its allies have suffered a series of economic and military setbacks ${ }^{19}$ and in which the Chinese state's projects of expansion and accumulation have become more

16 Peter G Danchin et al, 'The Pandemic Paradox in International Law' (2020) 114(4) American Journal of International Law 598, 605-7.

17 While writing this article in February 2021, the United States ('US') had recorded 471,000 deaths, the United Kingdom ('UK') 114,000 and the Netherlands 14,000 of a total 2.35 million deaths recorded globally.

18 Nial MacCarthy, 'The Countries Best and Worst Prepared for an Epidemic' Forbes (Blog Post, 27 January 2020) <https://www.forbes.com/sites/niallmccarthy/2020/01/27/the -countries-best-and-worst-prepared-for-an-epidmic-infographic/?sh=717402d45799>.

19 For a measured engagement with US decline see Adam Tooze, 'Is This the End of the American Century?' London Review of Books (Blog Post, 4 April 2019) <https://www.lrb .co.uk/the-paper/v41/no7/adam-tooze/is-this-the-end-of-the-american-century>. 
successful. As such, the period has been one of intense rivalry, which has seen the US and its allies on the one hand and China on the other attempt to carve out international legal arguments that preserve and buttress their power. ${ }^{20}$ State responsibility is not the first or even the main international legal field where this strategic confrontation between imperial blocs unfolds. The protracted crisis of the Word Trade Organization ('wTo'), the South China Sea conflict and the revival of the veto powers at the UN Security Council are all instances of legalised confrontation.

What distinguishes this instance of inter-imperial competition from similar situations in the 2oth century is that historically, the Chinese state had been subordinated within a racialised global hierarchy. As China has grown in influence, racialised tropes about its 'secrecy' and 'inscrutability' have been repurposed and deployed in the context of an emergent rivalry. In part, attempts to cast China as the villain have drawn on this deeper well of racialised ideology to great effect. ${ }^{21}$ This is part of a much wider pattern, in which the US and its allies have cast rival states as threats to the international legal order which can be legally circumvented in the name of upholding the 'will of the international community'.22

China's approach to the question is in many respects the mirror image of that of 'the West'. Even though Chinese officials have not mobilised the idiom of state responsibility as such, the narrative that frozen food imports are to blame for the Wuhan wet market outbreak reveals China's own anxieties. If the Western narrative hinges on ideas of Chinese secrecy, animal cruelty and suboptimal hygiene, the Chinese narrative relies on growing anxieties about Chinese reliance on food imports and, more broadly, on an ambition to assume a more dominant global role. ${ }^{23}$ After all, if frozen food imports are to blame, then reducing or tightly controlling these imports will have a beneficial impact on Chinese public health. This approach is not any closer to the truth than the

$20 \quad$ See Robert Knox, 'Race, Racialisation and Rivalry in the International Legal Order' in Alexander Anievas, Nivi Manchanda and Robbie Shilliam (eds), Race and Racism in International Relations: Confronting the Global Colour Line (Routledge, 2014) 183-4.

21 On Sinophobic narratives in international law see Teemu Ruskola, Legal Orientalism: China, the United States, and Modern Law (Harvard University Press, 2013); Fatemah Albader, 'Coronavirus and the Resurgence of Sinophobia' (2020) 12(2) Tsinghua China Law Review 289.

22 See Robert Knox, 'Civilizing Interventions? Race, War and International Law' (2013) 26(1) Cambridge Review of International Affairs 111 ('Civilizing Interventions?').

23 It is telling of China's imperial ambitions that the debate about origins and responsibility has not been especially present in the English-language writings of Chinese international lawyers and officials. Rather, universalist concepts, such as the idea of 'global public goods', have encapsulated China's attempts to position itself as a global leader. 
idea of Chinese secrecy and lack of hygiene. However, it is an encapsulation of the mounting trade wars between not only China and the US, but also other regional competitors, notably Australia.

In part, then, the ideological functionality of legal invocations of state responsibility owes much to the enmeshment of the COVID-19 crisis within a wider political-economic and geopolitical context. International legal questions for state responsibility also have the ideological function of situating state actors within an international hierarchy. With this hierarchy thrown into doubt, inquiring into the origins of the pandemic has become a scientifically complex to the point of futility, but a politically and jurisprudentially generative endeavour to express inter-imperial rivalry and competition in international law in relation to CoviD-19.

\section{There's No Such Thing as a Natural Disaster}

In 2006, writing in the wake of Hurricane Katrina, the late Neil Smith famously declared 'there is no such thing as a natural disaster. ${ }^{24}$ By this, Smith did not deny that disasters have natural causes - in geography, physics, chemistry and biology. Rather, he insisted that these causes could not be separated from social relations. The social, political and economic practices of human beings crucially shape the very 'natural' factors which give rise to disasters. At the same time, the conditions in which disasters are 'received' - and indeed the question of whether a particular event reaches the scale of a disaster or not-are social products. As a consequence, the effect of such disasters is highly differentiated, based on socially-established levels of vulnerability and development.

The unfolding of the Covid-19 crisis has proved Smith's observation correct-and one clear example is in relation to food. While arguments emphasising food as the origin of CoviD-19 may be overdetermined by geopolitical competition, they cannot be dismissed out of hand. Rather, this focus is symptomatic of a real trend of industrialised, large-scale, export-orientated agriculture as the potential matrix of contagious disease. In this sense, the international legal focus on the Wuhan food market and China's handling of this outbreak presents a mystified image of a real problem. State responsibility both hints at and elides the complex interactions between a multitude of

24 Neil Smith, 'There's No Such Thing as a Natural Disaster', Items (Blog Post, 11 June 2006) $<$ https://items.ssrc.org/understanding-katrina/theres-no-such-thing-as-a-natural -disaster/>. 
actors in the modern food regime and the potential of their interactions to trigger outbreaks. ${ }^{25}$

Both recent and deeper trends in food production, distribution and consumption can help us to better comprehend this link between food production and disease ${ }^{26} \mathrm{~A}$ core Marxist proposition is that capitalism, as a mode of production, is inherently expansionary. Through this expansion different human activities are brought into the sphere of commodity production and circulation. Since these different human activities are distributed geographically, capitalism is also a spatially expansive regime. The most obvious example of this process is, of course, European imperialism and colonialism beginning with the 'discovery' of the Americas. In colonies, formal and informal, European capital found an opportunity for seemingly endless profits premised upon large-scale dispossession of native populations, intense exploitation of natural resources and of human labour, especially in the form of racialised slavery.

As environmental historian Jason W Moore has noted, this process of capitalist expansion is linked to ecological transformation in complicated ways. ${ }^{27}$ First, ecological transformation has historically brought about major shifts in global capitalism. Soil exhaustion due to monocultures was one of the primary reasons the centre of global sugar production shifted so often between the $15^{\text {th }}$ and 19th centuries. As the soil because exhausted, wood ran out, and even enslaved workers began to die at astonishing rates, new centres of sugar production emerged to replace those that had reached their ecological limit. At the same time, as the above example indicates, capitalist expansion is itself a major source of environmental transformation. The example of sugar production in Cuba is again instructive: the imperative to produce and trade as much sugar as possible produced a major climate shift in the island. The processing of the sugar cane is energy intensive requiring boiling furnaces for the production of semi-refined sugar. The combination of deforestation and ash produced by the burning of the cane altered Cuba's atmosphere and led to increased

25 The evolutionary biologist Rob Wallace has long drawn attention to the potential of largescale, transnational agri-businesses to trigger major epidemics, Rob Wallace, 'Big Farms Make Big Flu: Dispatches on Influenza, Agribusiness, and the Nature of Science' (Monthly Review Press, 2016).

26 For a comprehensive overview see Michael Fakhri, "The International Political Economy of the Right to Food' in Nehal Bhuta \& Rodrigo Vallejo (eds), Human Rights and Global Governance (Oxford University Press, forthcoming).

27 Jason W Moore, "The Modern World-System" as Environmental History? Ecology and the Rise of Capitalism' (2003) 32(3) Theory and Society 307 (“'The Modern World-System"'); Jason W Moore, 'Sugar and the Expansion of the Early-Modern World-Economy: Commodity Frontiers, Ecological Transformation and Industrialization' (2000) 23(3) Review (Fernand Braudel Center) 409. 
rainfall that persists to this day. ${ }^{28}$ This interaction between human production and ecology is not unique to capitalism. ${ }^{29}$ What is, though, historically distinct is that this entanglement between production and ecological transformation (and collapse) becomes global—as opposed to regional or national—under capitalism. Ecological shifts in, say, China can impact production, ecology and everyday life in the UK, Australia or South Africa.

We can understand the periodic emergence of new pathogens in the past few decades in this context. Industrialised agriculture and food production have been a crucial breeding ground for these new pathogens. As food production has become increasingly industrialised and transnational in scope, it has necessitated greater biological homogenization and elimination of biodiversity. Animals live in increasingly large facilities and under cramped conditions, while elimination of genetic diversity enables faster growing, slaughtering and transportation. This is a form of monoculture that increases productivity through the 'simplification of nature', ${ }^{30}$ but it also creates ecological conditions that facilitate disease.

Local growers are often not working independently, but are subcontractors for transnational agribusinesses. Their profit margins are tight and them cutting corners is common, while the contracts with the mother firm shift the risk for potential outbreaks to the grower. ${ }^{31}$ Finally, the destruction of forests, wetlands and other habitats means that birds and other wild animals are coming in contact with farm animals and humans increasing the chances of previously unknown pathogens jumping between species. In other words, the transformation of food production both in China and globally have created ideal conditions for the emergence of new, more dangerous pathogens. At the same time, the reduction of genetic diversity means that immunity firebreaks that might be able to slow down transmission have been removed. ${ }^{32}$

As noted above, it is not only in their emergence that pandemics such as COVID-19 can be understood as social phenomenon, capitalist social relations have also fundamentally shaped how pandemics are received. On the broadest level, the development of capitalism has been accompanied by patterns of urbanisation in which populations — and production—-become more densely

\footnotetext{
28 Ibid 425 .

29 Moore, "The Modern World-System" (n 27) 323.

30 This tendency toward the removal of biodiversity in the service of profitability is nothing new when it comes to capitalist agriculture, see Donald Worster, "Transformations of the Earth: Toward an Agroecological Perspective in History' (1990) 76(4) Journal of American History $1087,1101$.

$31 \quad$ Wallace (n 25) 356.

32 Ibid 56 .
} 
concentrated in urban regions. ${ }^{33}$ Such conditions, of course, are conducive to the spread of novel pathogens. More specifically, the particular paths of capitalist development have played a key role in determining the effects that the pandemic has had. Most obviously, countries have differing levels of healthcare infrastructure with which to respond to the virus, this affects both the ability of governments to cope with COVID-19 specifically, and the speed with which healthcare systems have been 'overwhelmed' by the virus. Beyond healthcare, the particular economic and demographic composition of societies plays a key role in how they can cope with the virus. States with ageing populations are of course more vulnerable to the effects of the virus.

Equally, however, the particular political-economic structure of a given state is crucial to controlling the virus. In the absence of established herd immunity, the most important mechanism has been to stop human circulation via lockdowns' and trace outbreaks of the virus. To sustain this requires an economy which can cope-at least temporarily—with lockdowns and the ability, and willingness, for governments to support the economy. At the same time, given the centrality of the workplace as a site of potential spread, governments must be able to control this as much as possible. Whilst this can be achieved by coercion to some degree, it also depends on the ability of the government to compensate workers via welfare payments. This also means that the particular form in which labour predominantly takes place is crucial, with informal and casual labour much harder to control and compensate.

The complex and uneven distribution of these factors is based upon patterns of global capitalist accumulation and forms of resistance to it. As a system of competitive accumulation capitalism tends towards forms of uneven development, in which wealth produces more wealth. ${ }^{34}$ Thus, in a capitalist system, the majority of resources are available to 'advanced' capitalist states. ${ }^{35}$ This asymmetry has been deepened by the processes of neoliberal restructuring that have occurred over the previous four decades, whereby-in the name of increased economic efficiency-welfare systems and health systems have been increasingly privatised, ${ }^{36}$ labour has been rendered more precarious and

33 David Harvey, 'The Right to the City' (2008) 53 New Left Review 23, 23.

34 Karl Marx, Capital: A Critique of Political Economy (Penguin, 1990) 711-854 ('Capital').

35 Such questions have been addressed under the rubric of 'imperialism'. The literature on this topic is vast, for an overview see Anthony Brewer, Marxist Theories of Imperialism: A Critical Survey (Routledge, 199o) ('Marxist Theories of Imperialism').

36 David Harvey, A Brief History of Neoliberalism (Oxford University Press, 2005). 
informal ${ }^{37}$ and organised labour has been defanged..$^{38}$ Of course, such processes have not gone uncontested, with those territories possessed of strong labour, socialist and communist movements often able to blunt the worst excesses of neoliberal restructuring.

It is in this context that we can understand the emergence and uneven spread of COVID-19 and its consequences. It spread through dense urban population centres, and then travelled via international flights, to the centres of accumulation in the capitalist world (in particular European capitals and the US). States with weaker welfare systems - including advanced capitalist centres of accumulation such as the US and UK-have struggled to lockdown effectively. At the same time, states with slum populations and informal employment economies, such as South Africa, have had difficulty dealing with the virus when it reaches them, the major exception being those territories—-such as Vietnam ${ }^{39}$ and Kerala ${ }^{40}$ - with strong welfare states and health provision.

The language of state responsibility is almost wholly inadequate to capture these dynamics. The ontology of state responsibility is one of methodological individualism, ${ }^{41}$ albeit one centring states and not physical persons. This centring of the state makes it very difficult to map out the complex interconnections between the state and other social forces, and in particular the

37 See Sibylle Marti, 'Precarious Work-Informal Work: Notions of "Insecure" Labour and How They Relate to Neoliberalism' (2019) 17(4) Journal of Modern European History 396 ('Precarious Work-Informal Work'). Importantly, Marti notes that informal labour has characterised labour markets in the Global South significantly prior to the advent of neoliberalism.

38 On the decline of union membership in Australia see Bradley Bowden, 'The Rise and Decline of Australian Unionism: A History of Industrial Labour from the 1820s to 2010' (2011) 100 Labour History 51. On the role of law in the curtailment of organised labour in the UK and Greece respectively see Robert Knox, 'Law, Neoliberalism and the Constitution of Political Subjectivity: The Case of Organised Labour' in Honor Brabazon (ed), Neoliberal Legality: Understanding the Role of Law in the Neoliberal Project (Routledge, 2016) 92; Ntina Tzouvala, '(Don't) Strike Back: Continuity and Rupture in Restraining the Right to Strike' in Honor Brabazon (ed), Neoliberal Legality: Understanding the Role of Law in the Neoliberal Project (Routledge, 2016) 119.

39 Thi Phuong Thao Tran et al, 'Rapid Response to the COVID-19 Pandemic: Vietnam Government's Experience and Preliminary Success' (2020) 10(2) Journal of Global Health ('Rapid Response to the COVID-19 Pandemic').

40 Jaideep C Menon et al, 'What Was Right about Kerala's Response to the COVID-19 Pandemic?' (2020) 5(7) BMJ Global Health. However, Kerala has been less successful in the 'second wave' of the pandemic, in part because — given its previous success—a large proportion of the population remained susceptible.

41 BS Chimni, 'The Articles on State Responsibility and the Guiding Principles of Shared Responsibility: A TWAIL Perspective' (2021) 31(4) European Journal of International Law 1211,1214 . 
relationship between states and capital. This is especially problematic as regards to the role that international actors play in the construction of state policies, especially in the Global South, where states often create and carry out policies in response to the pressure of 'international competition'. In part, this centring of the state is buttressed by the rules of attribution as articulated in the Articles on Responsibility of States for Internationally Wrongful Acts ('ARSIWA'). Here, the international responsibility of private actors is only imaginable as state responsibility as long as the extremely high threshold of attribution is reached. ${ }^{42}$

Whilst a more flexible test for attribution might be welcome, it would ultimately be unable to address the systemic context of disasters like CoviD-19. As our analysis has shown, there is simply not one 'actor' on whom 'responsibility' for the pandemic can be blamed. Rather, it is the outcome of capitalist social processes which occur, 'behind the backs' of those involved in them. ${ }^{43}$ The sense of linear causality inherent in the field of state responsibility-and international law more generally-means that both as a matter of substantive content and as a matter of form, state responsibility as a field is unable to capture the complex socio-economic processes that made CoviD-19 both possible and so devastating. Instead, it directs our attention towards the failure of particular states. At the same time, in seeking to fulfil the impossible task of finding a state 'responsible' for the pandemic, the language of state responsibility enables those 'who (directly or indirectly) live off the practices and processes' that have given rise to the pandemic 'to remain comfortably out of sight'.44

A Legal Virus?

On this reading, it would be tempting to see law's ideological function as purely an obscuring one, juxtaposed to the 'real' socio-economic processes generating the COVID-19 outbreak. However, as critical legal theories have taught us, we simply cannot separate out social and economic phenomena from the law, as

42 Ibid. 'What is equally troubling is that while ARsiwa benefitted corporations through rules of state responsibility, it also adopted a view on the doctrine of "attribution" that almost ruled out the possibility of making states responsible for their conduct' (emphasis omitted).

$43 \quad$ Marx (n 34) 135 .

44 Susan Marks, 'Human Rights and Root Causes' (2011) 74(1) Modern Law Review 57, 76. 
law itself plays a co-constitutive role in these relations. ${ }^{45}$ Insofar as CoviD-19 can be understood as a product of capitalist social relations, it is also a product of particular juridical regimes. Capitalism as a social system is structured around the legal institutions of property and contract, and - as many Marxists have argued-has a strong structural connection with law. ${ }^{46}$

Thus, when we look to the socio-economic context of the COVID-19 we can see that international law is intimately involved in almost every element of that context. As Anna Chadwick has argued, we cannot understand the industrialisation and transnationalisation of agriculture outside of specific legal changes at the domestic, transnational and international levels. In particular, since the ascendence of neoliberalism, agricultural liberalisation became a central concern of the International Financial Institutions ('IFIs'). ${ }^{47}$ Both the International Monetary Fund ('IMF') and World Bank made agricultural liberalisation a condition of their structural adjustment loans. ${ }^{48}$ Further conditionalities included currency devaluation-to make exports 'competitive' - and the lowering of trade barriers. The net result of this was that countries subject to structural adjustment loans were flooded with surplus food produced in the advanced centres of capital accumulation, which undercut domestic markets. This, combined with currency devaluation, created material incentives-and indeed compulsions-towards export-oriented production. ${ }^{49}$

Whilst China itself has not been subject to the IFIs, the liberalisation of agriculture was further cemented in the wT $0 .^{50}$ The aim has been to liberalise trade in general and remove any protectionist measures, or barriers to trade.

45 For the classical formulation of this, see Karl Klare, 'Law-Making as Praxis' [1979] 40 (Summer) Telos 123 .

46 Pashukanis (n 6); Ntina Tzouvala, Capitalism as Civilisation: A History of International Law (Cambridge University Press, 2020).

47 Anna Chadwick, Law and the Political Economy of Hunger (Oxford University Press, 2019) 39-48.

48 Ibid 39 .

49 For an example of how this played out in Haiti, see Jean-Germain Gros, 'Indigestible Recipe: Rice, Chicken Wings, and International Financial Institutions: Or Hunger Politics in Haiti' (2010) 40(5) Journal of Black Studies 974 ('Indigestible Recipe'). See Maj Grasten and Ntina Tzouvala, 'The Political Economy of International Transitional Administration: Regulating Food and Farming in Kosovo and Iraq' (2018) 24(5) Contemporary Politics 588 for an account of how such policies have been carried out under specific forms of transitional administration.

$5^{\circ}$ Michael Fakhri, 'Food as a Matter of Global Governance' (2015) 11(2) Journal of International Law and International Relations 68. 
This has generalised the conditions described above by subjecting agricultural sectors to international competitive pressures.

International law has also had a central role to play in creating the conditions in which the pandemic has been received. This is most obviously the case in terms of the legality of lockdowns. ${ }^{51}$ More importantly, international law has played a central role-particularly in the Global South-in shaping the political-economic conditions for managing the effects of CoviD-19. Through the medium of structural adjustment loans, the IF I s have demanded that states 'rebalance' their economies decisively towards free market solutions. This has led to the privatisation of many state services-including those related to heath - and the dismantling of systems of welfare and labour support. ${ }^{52}$ Indeed, despite rhetoric to the contrary, this continues in the present, with a recent Oxfam study showing that some $80 \%$ of coviD-related IMF loans have continued with austerity-driven structural adjustment programmes. ${ }^{53}$

On a deeper level, as Third World Approaches to International Law ('TWAIL') and Marxist scholarship have shown, international law historically played a central role in the birthing, consolidation and maintenance of a regime of racialised capitalism. Through its language of 'civilisation' international law supported the implantation and acceleration of industrial capitalism throughout the world. ${ }^{54}$ In the period subsequent to that international law has helped serve as a 'racial fix' to the problems of global capitalist accumulation, ${ }^{55}$

51 See Alan Greene, 'Derogating from the European Convention on Human Rights in Response to the Coronavirus Pandemic: If Not Now, When?' [2020] (3) European Human Rights Law Review 262; Tom Hickman, 'The Coronavirus Pandemic and Derogation from the European Convention on Human Rights' [2020] (6) European Human Rights Law Review 593; Kanstantsin Dzehtsiarou, 'Article 15 Derogations: Are They Really Necessary during the COVID-19 Pandemic?' [2020] (4) European Human Rights Law Review 359.

$5^{2}$ James Thuo Gathii, 'Good Governance as a Counter Insurgency Agenda to Oppositional and Transformative Social Projects in International Law' (1999) 5 Buffalo Human Rights Law Review 107; Sundhya Pahuja, 'Technologies of Empire: IMF Conditionality and the Reinscription of the North/South Divide' (2000) 13(4) Leiden Journal of International Law 749; Robert Knox, 'Against Law-Sterity' [2018] (6) Salvage 49.

53 Nadia Daar and Nona Tamale 'A Virus of Austerity? The COVID-19 Spending, Accountability, and Recovery Measures Agreed between the IMF and Your Government' Oxfam International (Blog Post, 12 October 2020) <https://www.oxfam.org/en/blogs/virus -austerity-covid-19-spending-accountability-and-recovery-measures-agreed-between -imf-and>.

54 Antony Anghie, Imperialism, Sovereignty, and the Making of International Law (Cambridge University Press, 2005); Robert Knox, 'Valuing Race? Stretched Marxism and the Logic of Imperialism' (2016) 4(1) London Review of International Law 81.

55 See Robert Knox, 'Haiti at the League of Nations: Racialisation, Accumulation and Representation' (2021) 21(2) Melbourne Journal of International Law 245. 
and helped maintain the dominant position of the US and European states throughout. As such, international law's role in conditioning the distribution of global resources goes beyond the IFIs and more deeply into its role in upholding unequal relationships of production and distribution in the global order. ${ }^{56}$

Here, then, we see a further - seemingly paradoxical-function of international law. It plays a constitutive in creating the social and economic conditions in which the COVID-19 pandemic was able to become a pandemic, yet it simultaneously effaces this role through its language of state responsibility. Insofar as any one state can be blamed for CoviD-19, international law's own role remains unspoken.

\section{Ideology, Legality, Responsibility}

Overall, the language of state responsibility carries a specific ontology in which the major actors in the world are states. It is then possible to trace consequences of these states' actions. But such a worldview is simply unable to capture the complex social context of the COVID-19 pandemic.

We previously noted that the one of the ideological effects of the language of state responsibility is to attempt to deflect responsibility from some states onto other states. What is true in this immediate and obvious sense is also true in a deeper level. By re-articulating the social nature of a pandemic as the failure of a given state actor, the language of state responsibility recasts three key elements of the CoviD-19 story. The overarching first issue is that the role of capitalism - in creating the conditions of urbanisation, trade, and unequal distributions of global wealth-in shaping the pandemic. To put it another way, social relations are rendered unintelligible within the framework of state responsibility.

Secondly, and linked to the first point, state responsibility renders the state a 'black box' in international law. There cannot be an account of the complex class stratifications and struggles that exist within states. Whilst states do play an important role in constructing global capitalism, there are a multitude of 'private' actors who have been core to the social context in which CoviD-19 has taken place. Perhaps most importantly, there are a number of actors—or, as we

56 Sundhya Pahuja, Decolonising International Law: Development, Economic Growth and the Politics of Universality (Cambridge University Press, 2011). 
might call them, 'ruling classes' - who have benefited from the conditions that have created the pandemic. ${ }^{57}$

Finally, the language of state responsibility is able to obscure the role that international law itself has played in creating the social conditions of the pandemic. Writing in the context of North Atlantic Treaty Organization ('NATO') intervention in Yugoslavia, Anne Orford notes that invocations of the necessity for 'action' in international law often belie the fact that the 'international community is already profoundly engaged in shaping the structure of political, social, economic, and cultural life in many states through the activities of international economic institutions. ${ }^{58}$ State responsibility exercises a similar role as it calls attention to international law only at a time of its putative violation, and so distracts from the broader constitutive role that law has played in the context of COVID-19.

The net effect of these invocations of state responsibility, then, is to insulate the deeper complicity between class, capitalism, international law and the COVID-19 crisis and rearticulate it as a simple story of state malfeasance. This can then feed directly into the unfolding rivalries that characterize the world order. The irony here is that in so doing international legal argument is actually productive of irresponsibility. Insofar as we can understand the CoviD-19 crisis as a socially produced one, with international law part and parcel of this social production, we can turn our attention to these processes. This would enable us to collectively take responsibility for transforming such processes in such a way as to mitigate their recurrence. But to do this would fundamentally call into question the very social foundations upon which the current world order is built, including those of international law.

57 Susan Marks, 'Human Rights and the Bottom Billion' [2009] (1) European Human Rights Law Review 37, 47.

58 Anne Orford, 'Locating the International: Military and Monetary Interventions after the Cold War' (1997) 38(2) Harvard International Law Journal 443, 459. 